NOTE

\title{
Ichthyophonus in sport-caught groundfishes from southcentral Alaska
}

\author{
Bradley P. Harris ${ }^{1, *}$, Sarah R. Webster ${ }^{1}$, Nathan Wolf ${ }^{1}{ }$ Jacob L. Gregg ${ }^{2}$, \\ Paul K. Hershberger ${ }^{2}$
}

${ }^{1}$ Alaska Pacific University, Fisheries Aquatic Science and Technology (FAST) Laboratory, 4101 University Drive,
Anchorage, AK 99508, USA

${ }^{2}$ US Geological Survey, Western Fisheries Research Center, Marrowstone Marine Field Station, 616 Marrowstone Point Road, Nordland, WA 98358, USA

\begin{abstract}
This report of Ichthyophonus in common sport-caught fishes throughout the marine waters of southcentral Alaska represents the first documentation of natural Ichthyophonus infections in lingcod Ophiodon elongates and yelloweye rockfish Sebastes ruberrimus. In addition, the known geographic range of Ichthyophonus in black rockfish $S$. melanops has been expanded northward to include southcentral Alaska. Among all species surveyed, the infection prevalence was highest $(35 \%, \mathrm{n}=334)$ in Pacific halibut Hippoglossus stenolepis. There were no gross indications of high-level infections or clinically diseased individuals. These results support the hypothesis that under typical conditions Ichthyophonus can occur at high infection prevalence accompanied with low-level infection among a variety of fishes throughout the eastern North Pacific Ocean, including southcentral Alaska.
\end{abstract}

KEY WORDS: Ichthyophonus $\cdot$ Pacific halibut $\cdot$ Lingcod $\cdot$ Rockfish $\cdot$ Pacific cod $\cdot$ Alaska

\section{INTRODUCTION}

Ichthyophonus spp. are mesomycetozoean parasites that have been reported in more than 145 fish hosts throughout the world (Gregg et al. 2016); however, some of these reports likely involve misidentifications, as other parasite(s) have been incorrectly reported as Ichthyophonus in several species of amphibians (Conway et al. 2015). High-severity infections have been associated with recurring epizootics in several commercially and recreationally important marine and freshwater fishes, including Atlantic and Pacific herring Clupea harengus and C. pallasii, respectively, mackerel Scomber scombrus, yellowtail flounder Pleuronectes ferruginea, Chinook salmon Oncorhynchus tshawytscha, American shad Alosa sapidissima, and several species of rockfish (Kent et al. 2001,

*Corresponding author: bharris@alaskapacific.edu
McVicar 2011, Burge et al. 2014). Gross signs of the disease vary among host species and may include white nodular lesions on the heart and other internal organs, ulcers in skeletal muscle, and 'sandpaper' skin - often accompanied by black ulcers on the epidermis. Sublethal effects may include reduced growth, reduced swimming stamina, and compromised overall fish health (McVicar 2011). The parasite genus contains several morphologically indistinguishable genotypes (Gregg et al. 2016), which may separate into distinct species. Neither distinguishing characteristics between species nor consensus on species nomenclature have been fully resolved; therefore, the parasite will hereafter be referred to generically as Ichthyophonus.

Although Ichthyophonus is known to infect many marine fishes, its known host distribution in the

() The authors 2018. Open Access under Creative Commons by Attribution Licence. Use, distribution and reproduction are unrestricted. Authors and original publication must be credited. 
marine waters of Alaska is limited to Pacific herring in the Gulf of Alaska, walleye pollock Gadus chalcogrammus in the Gulf of Alaska and Bering Sea, Chinook salmon in the Yukon and Kuskokwim rivers, and Pacific halibut Hippoglossus stenolepis in Prince William Sound, Cook Inlet, and the eastern Bering Sea (Eaton et al. 1991, Marty et al. 1998, 2010 Kocan et al. 2004, White et al. 2014, Gregg et al. 2016, Hershberger et al. 2018). The presence of Ichthyophonus in these fishes, all of which are important prey species at some point in their life histories, suggests that many other predatory fishes in the region are likely exposed to the parasite through trophic interactions. Further, Ichthyophonus infections are common in several rockfishes Sebastes spp. off the coasts of Ore-

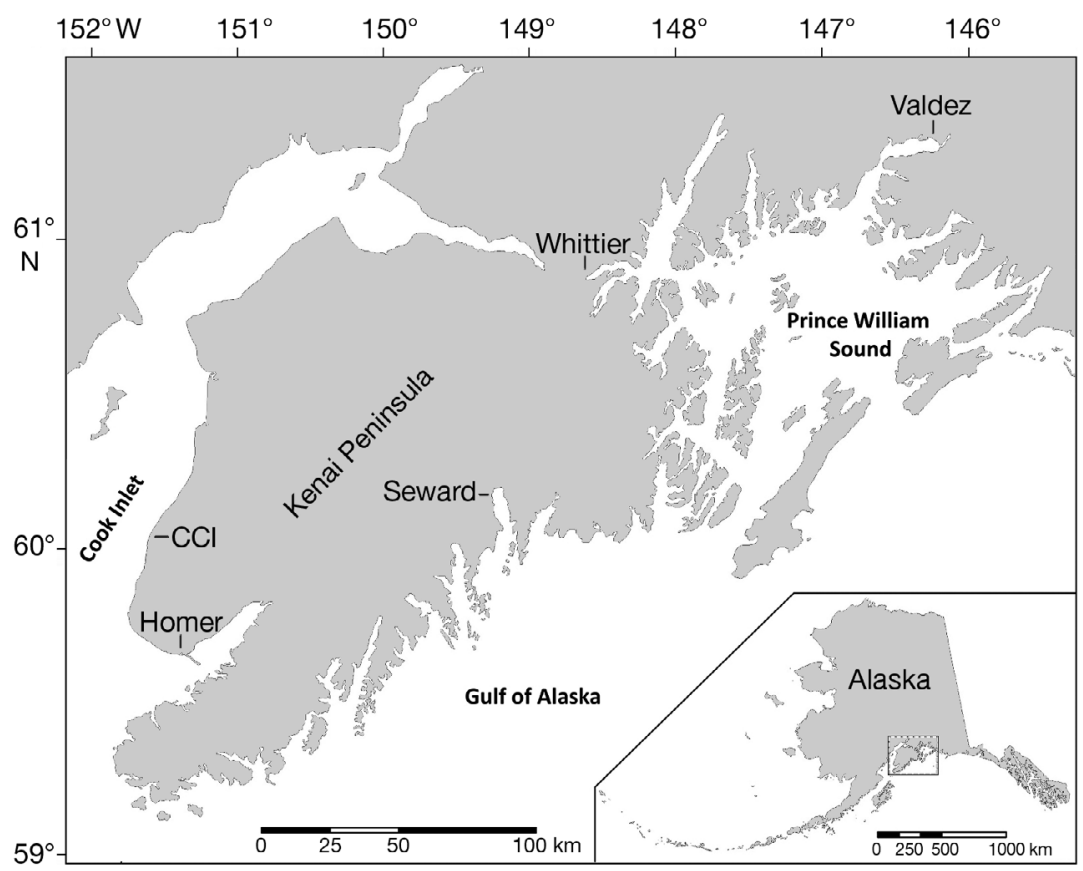

Fig. 1. Fishes were sampled at the ports of Homer, Central Cook Inlet (CCI), Seward, Whittier, and Valdez. Inset shows the location of the sampling areas in southcentral Alaska gon and Washington (Kent et al. 2001); however, its occurrence in these species in Alaskan waters has not yet been reported. The objective of this study was to determine the prevalence of Ichthyophonus in common sport-caught groundfishes in southcentral Alaska.

\section{MATERIALS AND METHODS}

The prevalence of Ichthyophonus infection in fishes from the marine regions of southcentral Alaska was assessed by sampling sport-caught specimens at municipal fish processing stations in the ports of Homer, Seward, Valdez, Whittier, and from Central Cook Inlet (CCI) near Ninilchik and Deep Creek (Fig. 1). Samples were collected after anglers were finished cleaning fish, but before the carcasses were discarded. Data from each fish included species identification, fork length $( \pm 1 \mathrm{~cm})$, sex, and Ichthyophonus infection status (described below). All sampling occurred at these ports simultaneously between 24 and 28 August 2011.

Ichthyophonus infection prevalence was determined by tissue explant culture. Heart tissue (approx. $0.5 \mathrm{~g}$ ) was collected from fish carcasses for in vitro Ichthyophonus culture. Only fish with intact pericardial cavities were sampled, and sampling tools were sterilized between fish to avoid cross-contamination
(LaPatra et al. 2008). The tissue was placed into $5 \mathrm{ml}$ of Eagle's minimum essential medium supplemented with fetal bovine serum (5\% v/v), penicillin (100 IU $\left.\mathrm{ml}^{-1}\right)$, streptomycin $\left(100 \mu \mathrm{g} \mathrm{ml}^{-1}\right)$, gentamycin $(100 \mu \mathrm{g}$ $\mathrm{ml}^{-1}$ ), and buffered to a $\mathrm{pH}$ of 7.8 with $1 \mathrm{M}$ Tris (Hershberger et al. 2002). Samples were refrigerated for $12-72 \mathrm{~h}$ before being incubated for $4 \mathrm{wk}$ at $16-18^{\circ} \mathrm{C}$. Cultures were examined microscopically ( $\times 40-100$ magnification) after 7,14 , and $28 \mathrm{~d}$ of incubation for the presence of Ichthyophonus life stages. A total of 5 reads were performed on each tissue sample, and samples were considered positive if Ichthyophonus stages including schizonts and germinating bodies were detected in at least 2 reads $\mathbf{1}$. Infection prevalence (the percentage of samples testing positive) and the corresponding binomial proportion $95 \%$ confidence interval was calculated for each port and species; in addition, the prevalence in Pacific halibut - the only species sampled in all 5 ports - was compared between ports. Statistical comparisons were performed using a $\chi^{2}$ test where sample sizes were $\geq 30$ individuals per species. Prior to initiating the tissue explant cultures, hearts were

\footnotetext{
1This protocol (multiple reads with $>1$ = positive infection) was employed because the readers were university students with Ichthyophonus microscopy experience limited to training by US Geological Survey staff for the purposes of this study.
} 
examined macroscopically for gross signs of ichthyophoniasis, including white nodules on the surface; infections were scored as high severity when gross signs were observed, and low severity when explant cultures were positive but gross signs were not observed.

\section{RESULTS}

Of the 668 fishes sampled from the 5 ports, $12 \%$ ( $\mathrm{n}=83$ ) of the Ichthyophonus cultures were unreadable because of overgrowth of mold and/or yeast contaminants; results presented here are based on observations from the uncontaminated cultures $(\mathrm{n}=585)$. Ichthyophonus was detected in fishes from all 5 ports and in 5 of the 10 species examined, including yelloweye rockfish Sebastes ruberrimus $(5 \%, \mathrm{n}=20)$, lingcod Ophiodon elongates $(16 \%, \mathrm{n}=45)$, black rockfish $S$. melanops $(9 \%, \mathrm{n}=56)$, Pacific cod Gadus macrocephalus $(9 \%$, $\mathrm{n}=58)$, and Pacific halibut $(35 \%, \mathrm{n}=334)$. The parasite was not detected in dusky rockfish $S$. ciliates (n = 46), canary rockfish $S$. pinniger $(\mathrm{n}=2)$, copper rockfish $S$. caurinus (n $=2$ ), silvergray rockfish $S$. brevispinis $(\mathrm{n}=4)$, or quillback rockfish $S$. malinger $(\mathrm{n}=18$; Table 1$)$. The combined infection prevalence in all species varied by port (17-44\%) and was strongly influenced by the proportion of Pacific halibut in each sample (Table 1). Samples from CCI had the highest Ichthyophonus prevalence (44 $\pm 10.1 \%$ ). In Pacific halibut - the only species examined in all 5 ports - infection prevalence varied (26-45\%) but was not significantly different among ports $\left(\chi^{2}=6.89\right.$, $\mathrm{df}=4$, $\mathrm{p}=0.14)$. Among infected fishes with $\mathrm{n} \geq 30$ samples (Pacific halibut, Pacific cod, black rockfish, and lingcod), Ichthyophonus prevalence did not vary by sex $(\mathrm{p}>0.8$; Table 2$)$. The minimum, mean and maximum fork lengths of the fishes sampled in this study are provided by port and species in Table 3 to support comparisons with other studies.

\section{DISCUSSION}

This report represents the first documentation of natural Ichthyophonus infections occurring in lingcod and yelloweye rockfish; in addition, the known geographic range of Ichthyophonus in black rockfish has been expanded northward to include southcentral Alaska. The results further expand on earlier documentation of Ichthyophonus in Pacific halibut in the region, which indicated $20-30 \%$ infection prevalence in lower Cook Inlet and Kachemak Bay, AK (Grenier 2014).

Table 2. Ichthyophonus infection prevalence in 4 species of sport-caught fishes from southcentral Alaska with total sample sizes $\geq 30$. Total fishes sampled (n), Ichthyophonus prevalence (prev, \%), the 95\% confidence interval ( \pm ) by species and sex

\begin{tabular}{|c|c|c|c|c|c|c|c|c|c|}
\hline \multirow[t]{2}{*}{ Species } & \multicolumn{3}{|c|}{ — Male- } & \multicolumn{3}{|c|}{ Female } & \multirow[t]{2}{*}{$\chi^{2}$} & \multirow[t]{2}{*}{ df } & \multirow[t]{2}{*}{$\mathrm{p}$} \\
\hline & $\mathrm{n}$ & Prev & \pm & $\mathrm{n}$ & Prev & \pm & & & \\
\hline Lingcod & 13 & 8 & 14.5 & 39 & 15 & 11.3 & 0.048 & 1 & 0.83 \\
\hline Black rockfish & 27 & 7 & 9.9 & 35 & 11 & 10.5 & 0.009 & 1 & 0.93 \\
\hline Pacific cod & 29 & 7 & 9.2 & 34 & 9 & 9.5 & 0.032 & 1 & 0.86 \\
\hline Pacific halibut & 113 & 35 & 8.8 & 217 & 35 & 6.4 & 0.0002 & 1 & 0.99 \\
\hline
\end{tabular}

Table 1. Ichthyophonus infection prevalence in 10 species of sport-caught fishes from southcentral Alaska. Total fishes sampled (n), Ichthyophonus prevalence (prev, \%) and the $95 \%$ confidence interval ( \pm ) by species and port. CCI: Central Cook Inlet

\begin{tabular}{|c|c|c|c|c|c|c|c|c|c|c|c|c|c|c|c|c|c|c|}
\hline \multirow[t]{2}{*}{ Species } & \multicolumn{3}{|c|}{$-\mathrm{CCI}=$} & \multicolumn{3}{|c|}{ —Homer —- } & \multicolumn{3}{|c|}{ - Seward - } & \multicolumn{3}{|c|}{ _ Valdez - } & \multicolumn{3}{|c|}{ —Whittier_— } & \multicolumn{3}{|c|}{ —All ports - } \\
\hline & $\mathrm{n}$ & Prev & \pm & $\mathrm{n}$ & Prev & \pm & $\mathrm{n}$ & Prev & \pm & $\mathrm{n}$ & Prev & \pm & $\mathrm{n}$ & Prev & \pm & $\mathrm{n}$ & Prev & \pm \\
\hline Canary rockfish & 0 & - & - & 0 & - & - & 0 & - & - & 0 & - & - & 2 & 0 & 0.0 & 2 & 0 & 0.0 \\
\hline Copper rockfish & 0 & - & - & 0 & - & - & 0 & - & - & 1 & 0 & 0.0 & 1 & 0 & 0.0 & 2 & 0 & 0.0 \\
\hline Silvergray rockfish & 0 & - & - & 0 & - & - & 0 & - & - & 0 & - & - & 4 & 0 & 0.0 & 4 & 0 & 0.0 \\
\hline Quillback rockfish & 0 & - & - & 0 & - & - & 1 & 0 & 0.0 & 0 & - & - & 17 & 0 & 0.0 & 18 & 0 & 0.0 \\
\hline Yelloweye rockfish & 0 & - & - & 0 & - & - & 2 & 0 & 0.0 & 3 & 33 & 53.3 & 15 & 0 & 0.0 & 20 & 5 & 9.6 \\
\hline Dusky rockfish & 0 & - & - & 39 & 0 & 0.0 & 7 & 0 & 0.0 & 0 & - & - & 0 & - & - & 46 & 0 & 0.0 \\
\hline Lingcod & 0 & - & - & 2 & 0 & 0.0 & 17 & 6 & 11.2 & 25 & 24 & 16.7 & 1 & 0 & 0.0 & 45 & 16 & 10.6 \\
\hline Black rockfish & 0 & - & - & 3 & 0 & 0.0 & 49 & 12 & 9.2 & 2 & 0 & 0.0 & 2 & 0 & 0.0 & 56 & 9 & 7.5 \\
\hline Pacific cod & 0 & - & - & 5 & 0 & 0.0 & 45 & 11 & 9.2 & 0 & - & - & 8 & 0 & 0.0 & 58 & 9 & 7.2 \\
\hline Pacific halibut & 93 & 44 & 10.1 & 126 & 26 & 7.7 & 41 & 39 & 14.9 & 36 & 27 & 14.3 & 38 & 45 & 15.8 & 334 & 35 & 5.1 \\
\hline All species & 93 & 44 & 10.1 & 175 & 19 & 5.8 & 162 & 17 & 5.8 & 67 & 25 & 10.3 & 88 & 19 & 8.2 & 585 & 23 & 3.4 \\
\hline
\end{tabular}


Table 3. The minimum, mean and maximum fork lengths $(\mathrm{cm})$, by species and port, of 10 species of southcentral Alaska sport-caught fishes sampled for Ichthyophonus. CCI: Central Cook Inlet

\begin{tabular}{|c|c|c|c|c|c|c|c|c|c|c|c|c|c|c|c|c|c|c|}
\hline \multirow{2}{*}{$\begin{array}{l}\text { Species } \\
\text { Canary rockfish }\end{array}$} & \multicolumn{3}{|c|}{$\begin{array}{l}-\mathrm{CCI}- \\
\text { Min. Mean Max. }\end{array}$} & \multicolumn{3}{|c|}{$\begin{array}{l}- \text { Homer }- \\
\text { Min. Mean Max. }\end{array}$} & \multicolumn{3}{|c|}{$\begin{array}{l}- \text { Seward }- \\
\text { Min. Mean Max. }\end{array}$} & \multicolumn{3}{|c|}{$\begin{array}{l}- \text { Valdez }- \\
\text { Min. Mean Max. }\end{array}$} & \multicolumn{3}{|c|}{$\begin{array}{l}\text { Whittier }- \\
\text { Min. Mean Max. }\end{array}$} & \multicolumn{3}{|c|}{$\begin{array}{l}- \text { All ports }- \\
\text { Min. Mean Max. }\end{array}$} \\
\hline & - & - & - & - & - & - & - & - & - & - & - & - & 67 & 70.5 & 74 & 67 & 70.5 & 74 \\
\hline Copper rockfish & - & - & - & - & - & - & - & - & - & 34 & 34 & 34 & 36 & 36 & 36 & 34 & 35.0 & 36 \\
\hline Silvergray rockfish & - & - & - & - & - & - & - & - & - & - & - & - & 31 & 39.0 & 46 & 31 & 39.0 & 46 \\
\hline Quillback rockfish & - & - & - & - & - & - & 40 & 40 & 40 & - & - & - & 33 & 38.8 & 45 & 33 & 38.8 & 45 \\
\hline Yelloweye rockfish & - & - & - & - & - & - & 43 & 53.5 & 64 & 32 & 49.7 & 60 & 40 & 50.1 & 59 & 32 & 50.4 & 64 \\
\hline Dusky rockfish & - & - & - & 29 & 37.3 & 44 & 34 & 37.7 & 43 & - & - & - & - & - & - & 80 & 105.6 & 129 \\
\hline Lingcod & - & - & - & 93 & 93.0 & 93 & 80 & 109.3 & 123 & 89 & 104.5 & 129 & 93 & 93 & 93 & 29 & 37.3 & 44 \\
\hline Black rockfish & - & - & - & 45 & 46.7 & 48 & 38 & 47.0 & 59 & 59 & 61.5 & 64 & 31 & 33.5 & 36 & 31 & 47.0 & 64 \\
\hline Pacific cod & - & - & - & 62 & 69.6 & 75 & 54 & 65.3 & 81 & - & - & - & 63 & 71.6 & 83 & 54 & 66.6 & 83 \\
\hline Pacific halibut & 65 & 85.1 & 152 & 62 & 80.5 & 119 & 59 & 78.5 & 120 & 63 & 84.9 & 147 & 58 & 82.5 & 105 & 58 & 82.2 & 152 \\
\hline
\end{tabular}

The relatively high prevalence of Ichthyophonus in Pacific halibut $(35 \%, \mathrm{n}=334)$ and lingcod $(16 \%, \mathrm{n}=$ 45) throughout the study region may be a reflection of the piscine generalist feeding strategies of these species. Ichthyophonus is easily transmitted to susceptible hosts through the consumption of infected fish tissues (Kocan et al. 2010). Throughout the eastern North Pacific Ocean, Pacific herring (Hershberger et al. 2016) and other forage species often demonstrate high infection prevalence and therefore represent a likely source of infection for piscivorous fishes, including Pacific halibut (Roseneau \& Byrd 2000, Orlov \& Moukhametov 2007) and lingcod (Cass et al. 1990, Tinus 2008). In contrast, the relatively low prevalence of Ichthyophonus in Pacific cod $(9 \%, \mathrm{n}=$ 58) may reflect reduced exposure to the parasite via the dominance of invertebrates in their diets (Urban 2012).

Lack of any apparent association between Ichthyophonus infection prevalence and Pacific halibut sex (Table 2) contrasts with a previously published report of the parasite in this host, where the infection prevalence was significantly greater in females (Hershberger et al. 2018). Reasons for this discrepancy remain unresolved, but may involve differences in geographical scale between the 2 studies; Hershberger et al. (2018) reported patterns over a much broader study area, including the eastern North Pacific Ocean and Bering Sea. Analogous differences in infection prevalence occur between male and female Atlantic herring (Kramer-Schadt et al. 2010) but not Pacific herring (Hershberger et al. 2016).

Complex and poorly understood epizootiological relationships between rockfishes and Ichthyophonus are indicated by dramatic differences in host infection prevalence and parasite genotypes throughout the eastern North Pacific Ocean. For example, high infection prevalence occurs in some species throughout Oregon, Washington, and British Columbia including Pacific Ocean perch Sebastes alutus (48\%) and yellowtail rockfish (51\%; Kent et al. 2001); however, low infection prevalence occurs among sympatric species including canary rockfish (5\%), yellowmouth rockfish (10\%; Kent et al. 2001), and Puget Sound rockfish $S$. emphaeus (11\%; Halos et al. 2005). An analogous low prevalence of infection occurred among all rockfishes surveyed throughout southcentral Alaska (Table 1), though inferences about Ichthyophonus prevalence in rockfishes based on these data are limited by small sample sizes. Interspecies differences in infection prevalence possibly result from differences in host species susceptibility, life history characteristics, and/or diet differences. In addition, differences in parasite tissue tropisms may also account for the apparent low prevalence in some rockfishes, as the parasite sometimes occurs in rockfish livers more often than in hearts, which were evaluated in this study (Kent et al. 2001, Halos et al. 2005).

Evaluation of the impacts to the host was beyond the scope of this study; however, there was no indication of overt disease in any sampled fishes. Although the infection prevalence in Pacific halibut (35\%) was relatively high, the documented infection severity in this host is typically very low (Grenier 2014, Hershberger et al. 2018). In addition, neither internal nor external gross signs, indicative of heavy infections, were detected in any of the fishes examined in this study. These observations support the hypothesis that Ichthyophonus often occurs as a chronic infection in Pacific halibut (Hershberger et al. 2018) and other marine hosts, causing little or no apparent harm under typical conditions. However, in response to poorly understood environmental conditions that 
likely involve periods of punctuated exposure and high population densities, overt ichthyophoniasis epizootics can occur in association with massive fish kills (reviewed in McVicar (2011) and Burge et al. (2014)), emphasizing the need to continue to monitor Ichthyophonus prevalence and infection severity throughout its known host and geographic range.

Acknowledgements. This project relied on strong partnerships with the Alaska Department of Fish and Game, Division of Sport Fish, Groundfish Research Program in Homer, $\mathrm{AK}$, and the US Geological Survey Marrowstone Marine Field Station. Support provided by the sport-charter fishing industry and fillet businesses in the port of Homer, in particular, North Country Charters and Buttwhackers, was invaluable. Field sampling and culture reads were performed by Alaska Pacific University students in B.P.H.'s 2011 ichthyology course with heart sampling and culture read training provided by J.L.G. Laboratory supplies and training were provided with the support of the 'Exxon Valdez' Oil Spill Trustee Council (Project \#17120111-E), the Pollock Conservation Cooperative, and the US Geological Survey Fisheries Program, Ecosystems Mission Area. The use of trade, firm, or corporation names in this publication is for the information and convenience of the reader. Such use does not constitute an official endorsement or approval by the US Government of any product or service to the exclusion of others that may be suitable.

\section{LITERATURE CITED}

Burge CA, Eakin CM, Friedman CS, Froelich B, Hershberger PK, Hofmann EE, Harvell CD (2014) Climate change influences on marine infectious diseases: implications for management and society. Annu Rev Mar Sci 6:249-277

Cass AJ, Beamish RJ, McFarlane GA (1990) Lingcod (Ophiodon elongatus). Can Spec Publ Fish Aquat Sci 109: 40

Conway CM, Purcell MK, Elliott DG, Hershberger PK (2015) Detection of Ichthyophonus by chromogenic in situ hybridization. J Fish Dis 38:853-857

Eaton WD, Kent ML, Meyers TR (1991) Coccidia, X-Cell pseudotumors and Ichthyophonus sp. infections in walleye Pollock (Theregra chalcogramma) from Auke Bay, Alaska. J Wildl Dis 27:140-143

*Gregg JL, Powers RL, Purcell MK, Friedman CS, Hershberger PK (2016) Ichthyophonus parasite phylogeny based on ITS rDNA structure prediction and alignment identifies six clades, with a single dominant marine type. Dis Aquat Org 120:125-141

Grenier C (2014) Quantifying Ichthyophonus hoferi prevalence and load in Pacific halibut (Hippoglossus stenolepis) organs within the Cook Inlet, Alaska. MSc thesis, Alaska Pacific University, Anchorage, AK

* Halos D, Hart A, Hsu H, Hershberger P, Kocan R (2005) Ichthyophonus in Puget Sound rockfish, Sebastes emphaeus from the San Juan archipelago and Puget Sound, Washington, USA. J Aquat Anim Health 17: 222-227
Hershberger P, Stick K, Bui B, Carroll C and others (2002) Incidence of Ichthyophonus hoferi in Puget Sound fishes and its increase with age of Pacific herring. J Aquat Anim Health 14:50-56

*Hershberger PK, Gregg JL, Hart LM, Moffitt S and others (2016) The parasite Ichthyophonus sp. in Pacific herring. J Fish Dis 39:395-410

* Hershberger PK, Gregg JL, Dykstra CL (2018) High-prevalence and low-intensity Ichthyophonus infections in Pacific halibut. J Aquat Anim Health 30:13-19

Kent M, Watral V, Dawe S, Reno P, Heidel J, Jones S (2001) Ichthyophonus and mycobacterium-like bacterial infections in commercially-important rockfish, Sebastes spp., in the eastern North Pacific Ocean. J Fish Dis 24: 427-431

Kocan RM, Hershberger PK, Winton J (2004) Ichthyophoniasis: an emerging disease of Chinook salmon in the Yukon River. J Aquat Anim Health 16:58-72

Kocan RM, Gregg JL, Hershberger PK (2010) Release of infectious cells from epidermal ulcers in Icthyophonus sp.-infected Pacific herring (Clupea pallasii): evidence for multiple mechanisms of transmission. J Parasitol 96: 348-352

Kramer-Schadt S, Holst JC, Skagen D (2010) Analysis of variables associated with the Ichthyophonus hoferi epizootics in Norwegian spring spawning herring, 1992-2008. Can J Fish Aquat Sci 67:1862-1873

* LaPatra S, Kocan R, Hershberger P (2008) Potential for crosscontamination of in vitro explant cultures initiated from Ichthyophonus-infected rainbow trout, Oncorhynchus mykiss (Walbaum). J Fish Dis 31:317-320

*Marty GD, Freiberg E, Meyers T, Wilcock J, Farver T, Hinton D (1998) Viral hemorrhagic septicemia virus, Ichthyophonus hoferi, and other causes of morbidity in Pacific herring Clupea pallasi spawning in Prince William Sound, Alaska, USA. Dis Aquat Org 32:15-40

*Marty GD, Hulson PJF, Miller SE, Quinn TJ, Moffitt SD, Merizon RA (2010) Failure of population recovery in relation to disease in Pacific herring. Dis Aquat Org 90: $1-14$

McVicar AH (2011) Ichthyophonus In: Woo PTK, Bruno DW (eds) Fish diseases and disorders, Vol 3: viral, bacterial, and fungal infections, 2nd edn CABI, Cambridge, p 721-747

Orlov AM, Moukhametov IN (2007) Comparative characteristics of feeding of Pacific halibut Hippoglossus stenolepsis from various regions of north-western part of Pacific Ocean. J Ichthyol 47:739-749

Roseneau DG, Byrd GV (2000) Using predatory fish to sample forage fishes, 1995-1999. Exxon Valdez oil spill APEX project annual report. US Fish and Wildlife Service, Alaska Maritime National Wildlife Refuge, Homer, AK

Tinus CA (2008) Prey preference of Lingcod (Ophiodon elongatus), a top marine predator: implications for ecosystem-based fisheries management. Fish Bull 110: 193-205

U Urban D (2012) Food habits of Pacific cod and walleye pollock in the northern Gulf of Alaska. Mar Ecol Prog Ser 469:215-222

White VC, Morado JF, Friedman CS (2014) Ichthyophonusinfected walleye pollock Theragra chalcogramma (Pallas) in the eastern Bering Sea: a potential reservoir of infections in the North Pacific. J Fish Dis 37:641-655 